\title{
CRITICAL PHENOMENA: 150 YEARS SINCE CAGNIARD DE LA TOUR
}

\author{
Bertrand Berche ${ }^{1}$, Malte Henkel ${ }^{1}$, Ralph Kenna ${ }^{2}$ \\ ${ }^{1}$ Département de Physique de la Matière et des Matériaux, Institut Jean Lamour, \\ Laboratoire associé au CNRS UMR 7198, CNRS-Nancy Université-UPVM, \\ B. P. 70239, F-54506 Vandouvre lès Nancy Cedex, France, \\ ${ }^{2}$ Applied Mathematics Research Centre, Coventry University, Coventry CV1 5FB, England
}

(Received September 3, 2009; received in final form October 16, 2009)

\begin{abstract}
Critical phenomena were discovered by Cagniard de la Tour in 1822, who died 150 years ago. In order to mark this anniversary, the context and the early history of his discovery is reviewed. We then follow with a brief sketch of the history of critical phenomena, indicating the main lines of development until the present date.
\end{abstract}

Key words: phase transitions, critical phenomena.

PACS number(s): 01.00.00, 01.60.+q, 01.65.+g, 05.00.00, 05.70.Fh, 05.70.Jk

Baron Charles Cagniard de la Tour (17771859), who died 150 years ago, was the discoverer of critical phenomena. What started as an exotic curiosity has developed into a mature field underlying the modern-day physics of many-body and complex systems. Here the circumstances surrounding his discovery are reported, and the evolution of the field to the present-day is synopsised.

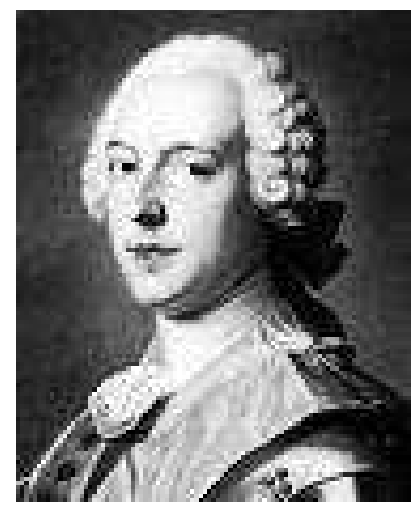

Fig. 1. Portrait of Cagniard de la Tour, courtesy of the Universidade do Minho, Portugal.

Born in Paris in 1777, Charles Cagniard was educated at l'École Polytechnique, and went on to become a prolific scientist and inventor. Besides his discovery of critical phenomena, Cagniard de la Tour investigated the nature of yeast and its role in the fermentation of alcohol and was interested the physics of the human voice as well as bird flight. His interest in acoustics led to the invention of the siren (see figure 2), which he named after sea creatures from Greek mythology who lured sailors to their doom.

Experiments on steam engines in the late 17th and early 18th centuries motivated interest in the behaviour of fluids at high temperatures and pressures. Denis Papin (1647-1712) who invented the "steam digester" - a forerunner of the steam engine - noticed that when heated under pressure, water remains in its liquid phase at temperatures far greater than the usual boiling point of $100^{\circ} \mathrm{C}$ : the temperature of the boiling point increases with increasing pressure.

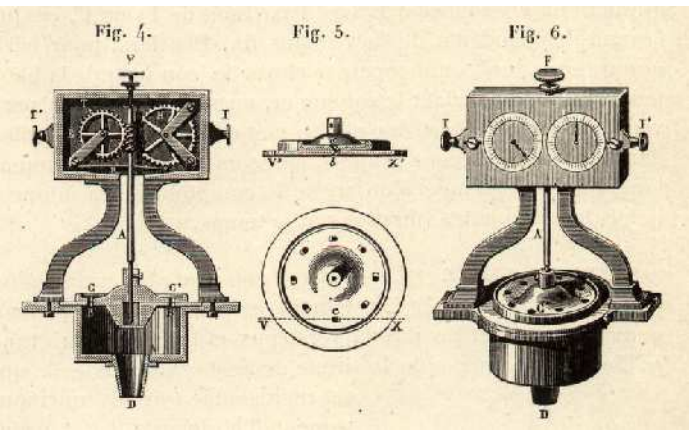

Fig. 2. The improved siren, invented and named by Charles Cagniard de la Tour. Photograph courtesy of the École Polytechnique Paris, France.

The term "latent heat", for the energy required to complete a solid-liquid or liquid-vapour phase transition, was introduced around 1750 by Joseph Black (1728-1799). In 1783 James Watt (1736-1819) analysed its dependency on pressure, and found that the latent heat of vaporisation decreases as the temperature is increased. At this time, gases were considered to be distinct from vapours (produced by evaporating liquids). "Elastic flu$i d s$ " which were not reducible to liquid form were termed gases. It was in the second half of the 18th century that Antoine-Laurent de Lavoisier (1743-1794) showed gases and vapours to be one and the same, and a third state of matter beside solids and liquids. He also suggested that gases could be liquefied at sufficiently low temperature and high pressure [1].

The first successful experiments on liquefaction of gases took place in 1784, when Jean-François Clouet (17511801) and Gaspard Monge (1746-1818) achieved the liquefaction of gaseous sulphur dioxide by cooling and compression. There followed a sequence of successful experiments, including by chemist and physicist Michael Faraday (1791-1867), in which gases were liquefied, thus removing the distinction between vapour and gas [2,3]. Hydrogen, oxygen, nitrogen, and carbon monoxide, which were previously thought to be incondensably gaseous and were called "permanent gases" were eventually liquefied 1877. 
The discovery of what we now call the critical point came about with Cagniard de la Tour's experiments with Papin's digester. In 1822, in the context of his interests in acoustics, he placed a flint ball in a digester partially filled with liquid. Upon rolling the device, a splashing sound was generated as the solid ball penetrated the liquid-vapour interface. Cagniard de la Tour noticed that upon heating the system far beyond the boiling point of the liquid, the splashing sound ceased above a certain temperature. This marks the discovery of the supercritical fluid phase. In this phase there is no surface tension as there is no liquid-gas phase boundary. The supercritical fluid can dissolve matter like a liquid and can diffuse through solids like a gas.

\section{(12y)}

dans les unes comme dans les autres; et nous savons que, dans les glacières artificieltes, il n'y a d'autro capse de froid que la glace qu'on y aceumule. Plus la glacière approche des glacières naturelles parsa grandeur, et plns on y accumule de glace, plus celle-ci se conserve longtemps.

\section{Expost de quelques rësultats obtenus par' l'action combinée de la cháleur et de la compression sur certains liquides, tels.que l'eau, l'alcool, l'éthér sulfurique et l'essence de pétrole rectifiée.}

\section{Par M. le Baron' Clagiand de La Tour.}

Or sait qu'au moyen de la marmite à Papin on peut étever la temperature des liquiles beaucoup au-dessus du terme ordinaire de leur ébullition ; 'et l'on est porte a croire que la compression intérieure qui s'angmente avec la température devrait être un obstacle à l'évaporation totale du liquide, súrtout si l'espace laissé au-dessus de ce liquide n'est pas d'une certaine étendue.

En ý réflếchissant, il m'est venu à la pensée que la dilatation d'un liquide volatil avait nécessairement une limite au-delà de laquelle ce liquide devait, malgrè la compression, passer à l'état de vapeur, pour pen que la capacité de l'appareil pernit d̀ la matièré liquide de $s^{2} \&$ tendre au-delà de son maximum de d̛́latation. . . . :

Pour vérifier ce fait 'f'ái intròduit dans ‘ une petite marnite a Papin, eonstruite avec un bout de canon de fusil très-épais ; une certaine quantité d'alcơal a 36 do-

Fig. 3. The first page of Cagniard de la Tour's article, in which the discovery of critical phenomena is reported.

In two articles (see figure 3) in the Annales de Chimie et de Physique [4], Cagniard de la Tour described how he heated a sealed glass tube of alcohol under pressure. He observed that the liquid expanded to approximate- ly twice its original volume, and then vanished, having been converted to a vapour so transparent that the tube appeared completely empty. On re-cooling the system a thick cloud appeared. We now recognise this as an observation of critical opacity and the discovery of the critical point. He also observed that beyond a certain temperature, increasing the pressure did not prevent the evaporation of the liquid.

In a following paper, Cagniard de la Tour reported upon a series of related experiments with a variety of substances [5]. Desiring to demonstrate that the existence of a limiting temperature above which a liquid vapourises irrespective of pressure is a general phenomenon, he experimented on water, alcohol, ether and carbon bisulphide. He measured the critical temperature at which the interface tension vanished, as determined by the disappearance of the meniscus, and discovered that for each substance, there is a certain temperature beyond which total vaporisation of the liquid occurs and where no increase in pressure will liquefy the gas. In the case of water, this critical temperature was estimated to be $362^{\circ} \mathrm{C}$, a remarkably accurate result (modern measurements give $374^{\circ} \mathrm{C}$ ). His experiments demonstrated that this "état particulier" requires high temperatures, almost independent of the volume of the tube: "... cet état particulier exige toujours une température très-élevée, presque indépendante de la capacité du tube" [5]. We now know that the état particulier marks the critical end-point of a line of first-order phase transitions, where the transition becomes continuous.

While many of Cagniard de la Tour's contemporaries regarded his results as being particular to the substances involved rather than a general phenomenon [6], Faraday recognised the significance of his work [3]. In a letter to William Whewell in 1844, Faraday wrote [7] "Cagniard de la Tour made an experiment some years ago which gave me occasion to want a new word". Referring to what we now call the critical point, he continued, "how am I to name this point at which the fluid \& its vapour become one according to a law of continuity? Cagniard de la Tour has not named it; what shall I call it?" Whewell suggested to call it the point of vaporiscience or the point at which fluid is disliquified or the Tourian state, and in a later publication Faraday refers to "Cagniard de la Tour's state" and "the Cagniard de la Tour point" [8]. In 1861, Dmitri Mendelejeff (1834-1907), referred to it as the " $a b$ solute Siedetemperatur", or absolute boiling point [9].

In 1869, the term we now use - the critical point - was eventually coined by Thomas Andrews (18131885), who further elucidated the meaning of Cagniard de la Tour's état particulier [10]. Andrews studied the pressure-volume curve of the liquid-vapour coexistence line of carbonic acid and clarified that a gas may only condense to a liquid, or a liquid evaporate to a gas, below certain values of the temperature and pressure - the état particulier. Beyond this point lies the supercritical phase, where the distinction between liquid and vapour disappears.

In what followed, the early experiments of Cagniard de la Tour blossomed into a large-scale intellectual ad- 
venture, which we now proceed to outline. The following reflects our personal points of view and experiences in the field. In 1873, Johannes Diderik van der Waals (1837-1923) showed in his doctoral thesis [11] that Andrews' experimentally based equation of state may be explained qualitatively using an extension of the ideal gas law which modelled molecular attraction and hardcore repulsion in a simple manner. This in turn suggested to Heike Kamerlingh Onnes (1853-1926) how to estimate the critical points for 'permanent gases', which gave the conceptual bases for the eventual liquefaction of helium, followed soon after by the discovery of superconductivity. On the other hand, the simple mean-field values of the "critical exponents" obtained from his equations are not adequate for a quantitative description of real systems, as realised experimentally in 1896 by Jules-Émile Verschaffelt (1870-1955). Mean-field treatments were systematised in the phenomenological theory of Lev Davidovich Landau (1908-1968), where phase transitions in all spatial dimensions were predicted [12].

On the other hand, the important concept of "universality" of critical phenomena was introduced by Pierre Curie (1859-1906), who discovered that ferromagnetic materials become demagnetised above a critical temperature [13] which is often referred to as the "Curie point". Formal analogies between a priori unrelated physical systems have been of great usefulness in trying to understand critical phenomena and were also one of the motivations when Wilhelm Lenz (1888-1957) introduced the simple many-body system now usually called "Ising model" [14]. Ernst Ising (1900-1998) solved the one-dimensional case in his doctoral thesis (1924) under Lenz, and the absence of a phase transition there clearly showed that a conceptual explanation of the critical point beyond the level of mean-field theories had to be sought. This conclusion was further strengthened by the achievements of Lars Onsager (1903-1976), who in 1944 calculated exactly the specific heat of the twodimensional Ising model in the absence of an external magnetic field and in 1949 announced the correct formula for the spontaneous magnetisation, proven by C.N. Yang (born 1922) in 1952. By a tour de force and combining techniques of conformal field-theory with integrable systems, Alexander Zamolodchikov (born 1952) showed in 1989 that the two-dimensional Ising model in an external magnetic field, but with the temperature fixed to the critical temperature, is integrable [15].

In view of the absence of an exact solution for the three-dimensional Ising model, numerical techniques came to the fore. These are based either on systematic expansions around the known extreme cases of very high or very low temperatures as suggested by Cyril Domb (born 1920) in his doctoral thesis in 1949 [16], or else are based on large-scale simulations which go under the name of the "Monte Carlo method" and suggested in 1949 by John v. Neumann (1903-1957), Nicholas Metropolis (1915-1999) and Stanislaw Ulam (1909-1984) [17].

In the 1960's it was realised by several workers including Benjamin Widom (born 1927), Alexander Patashinskii (born 1936) and Valery Pokrovsky (born 1931), Leo Kadanoff (born 1937) and Michael Fisher (born 1931) that a general theoretical framework for phase transitions would have to be formulated in terms of a "scaling theory" which in particular led to "scaling relations" between the critical exponents which describe the behaviour of the various measurable quantities close to a critical point. This opened the way to a full theoretical description of critical phenomena through the "renormalisation group" by Kenneth Wilson (born 1936) in 1971 following applications to quantum electrodynamics by Nikolay Bogolyubov (1909-1992) and Dmitry Shirkov (born 1928) in 1959. This has been the basis for very accurate predictions of the values of the critical exponents in two and three dimensions.

On the other hand, since the days of Cagniard de la Tour experimental techniques have been continuously refined. In a celebrated series of experiments, nearlogarithmic or weak-power-law behaviour for the divergences in the specific heat of helium and argon were found [18], thereby giving experimental evidence of nonLandau behaviour. Very precise estimates for the values of the critical exponents can nowadays be obtained. For a long time, however, while experimentalists were busy measuring the critical behaviour of three-dimensional bulk systems, theorists could only calculate exactly the critical behaviour of two-dimensional systems, which can only be realised at the surface of some substrate. It took surprisingly long until phase transitions for systems confined to a surface were experimentally observed. The first confirmed example seems to have been found in Nancy by André Thomy in his thèse 3ème cycle (1959) for krypton adsorbed on graphite [20]. Fittingly, this discovery arose exactly a century after the death of Cagniard de la Tour.

Nowadays, the most precise experiments are carried out on board the space shuttle, the space station MIR and the International Space Station. As an example, we quote the result for the specific-heat exponent $\alpha=$ $0.11 \pm 0.03$ obtained for the critical point in the simple fluid $\mathrm{SF}_{6}$ during the Spacelab D2 mission (1999), in good agreement with the current theoretical estimate $\alpha=0.109 \pm 0.002$ [19]. (Mean-field theory would have predicted $\alpha=0$.)

In the 150 years since its inception, the field of critical phenomena has blossomed and now forms a cornerstone of modern physics, both experimental and theoretical and this development nicely illustrates how a topic of purely fundamental research, given enough time, can diversify into initially unforeseeable directions. Its founder, Charles Cagniard de la Tour died in Paris on the $5^{\text {th }}$ of July 1859 . 
[1] A.-L. Lavoisier, in Mémoires de chimie, Tome Premier (Paris, 1805), p. 348.

[2] M. Faraday, H. Davy, Phil. Trans. R. Soc. Lond. 113, 160 (1823); M. Faraday, Phil. Trans. R. Soc. Lond. 113, 189 (1823).

[3] M. Faraday, Quart. J. Sci., Literature and the Arts 16 229 (1823); reprinted in The Liquefaction of Gases. Papers by Michael Faraday, F. R. S. (1823-1845) with an Appendix consisting of Papers by Thomas Northmore in the Compression of Gases (1805-1806), Alembic Club Reprint No. 12 (William F. Clay, Edinburgh and Simpkin, Marshall, Hamilton, Kent \& Co., London, 1896), p. 19.

[4] C. Cagniard de la Tour, Ann. Chim. Phys. 21, 127 (1822); Ann. Chim. Phys. 21, 178 (1822).

[5] C. Cagniard de la Tour, Ann. Chim. Phys. 22, 410 (1823).

[6] Y. Goudaroulis, Revue d'Histoire des Sciences 47, 353 (1994).

[7] M. Faraday, letter to W. Whewell, 9th November 1844. See [6] and references therein.

[8] M. Faraday, Phil. Trans. 135, 155 (1845); reprinted in The Liquefaction of Gases. Papers by Michael Faraday, F. R. S. (1823-1845) with an Appendix consisting of Papers by Thomas Northmore in the Compression of Gases (1805-1806), Alembic Club Reprint No. 12 (William F. Clay, Edinburgh and Simpkin, Marshall, Hamilton, Kent \& Co., London, 1896), p. 19.

[9] D. Mendelejeff, Ann. Chem. Pharm. 119, 1 (1861).

[10] T. Andrews, Phil. Trans. Roy. Soc. Lond. 159, 575 (1869).
[11] J. D. van der Waals, doctoral thesis (Leiden, 1873); reprinted in On the continuity of gaseous and liquid states, ed. with an introductory essay by J. S. Rowlinson (North-Holland Amsterdam, 1988).

[12] L. D. Landau, Nature 137, 840 (1936).

[13] P. Curie, Archiv. Sci. Phys. Nat., 3e période 26, 13 (1891); reprinted in: Oeuvres de Pierre Curie (GauthierVillars, Paris, 1908), p. 214.

[14] W. Lenz, Phys. Z. 21, 613 (1920); E. Ising, Z. Phys. 31, 253 (1925).

[15] A. B. Zamolodchikov, Adv. Stud. Pure Math. 19, 641 (1989).

The exact equation of state of an explicitly solvable model in the universality class of the $2 \mathrm{D}$ critical Ising model in an external field was given by S. O. Warnaar, P. A. Pearce, K. A. Seaton, B. Nienhuis, J. Stat. Phys. 74, 469 (1994).

[16] C. Domb, The critical point: a historical introduction to the modern theory of critical phenomena (Taylor \& Francis, London, 1996).

[17] N. C. Metropolis, Los Alamos Science 15, 125 (1987).

[18] W. M. Fairbank, M. J. Buckingham, C. F. Kellers, Proceedings of the Fifth International Conference on Low Temp. Phys., (Madison, WI, 1957), p. 50; M. I. Bagatskii, A. V. Voronel', B. G. Guzak, Zh. Eksp. Teor. Fiz. 728 43, (1962) [Sov. Phys. - JETP 16, 517 (1963)].

[19] M. Barmatz, I. Hahn, J. A. Lipa, R. V. Duncan, Rev. Mod. Phys. 79, 1 (2007).

The experimental estimate for $\alpha$ quoted in the text is from A. Haupt, J. Straub, Phys. Rev. E59, 1795 (1999).

[20] A. Thomy, X. Duval, J. Chim. Phys. 67, 1101 (1970).

\title{
КРИТИЧНІ ЯВИЩА: 150 РОКІВ ВІД КАНЬЯРА ДЕ ЛЯ ТУРА
}

\author{
Бертран Берш ${ }^{1}$, Мальте Генкель ${ }^{1}$, Ральф Кенна ${ }^{2}$ \\ ${ }^{1}$ Інститут Жана Лямура, Універсистет Нансі, Франція, \\ ${ }^{2}$ Центр прикладних математичних досліджень, Університет Кавентрі, Англія
}

Критичні явища відкрив Каньяр де ля Тур у 1822 році. Дослідник відійшов у вічність 150 років тому, 1859 року. Вшановуючи цю річницю, подаємо огляд передісторії його відкриття. Відтак переходимо до короткого нарису історії критичних явищ, зосереджуючи увагу на основних віхах розвитку цієї теорії аж до сьогодні. 